\title{
PRORAČUN PRIKLJUČAKA U REŠETKASTIM ČELIČNIM NOSAČIMA PREMA EUROKOD NORMAMA
}

\author{
Iva Knežević \\ Sveučilište J. J. Strossmayera u Osijeku, Građevinski fakultet Osijek, student \\ Milijana Mikolin \\ Sveučilište J. J. Strossmayera u Osijeku, Građevinski fakultet Osijek, dipl.ing.građ. \\ Damir Markulak \\ Sveučilište J. J. Strossmayera u Osijeku, Građevinski fakultet Osijek, prof.dr.sc.
}

Sažetak: U radu se obrađuje kodificirani proračun priključaka rešetkastih čeličnih nosača prema [1] i [2]. Pravila iz [1] koja se odnose na zavarene priključke u čeličnim rešetkastim nosačima su specifična i vrijede u vrlo ograničenim uvjetima, stoga se daje prikaz tih ograničenja te postupak dokaza otpornosti priključaka. $\mathrm{Na}$ numeričkom primjeru rešetkastog nosača od šupljih kvadratnih profila s direktnim zavarivanjem štapova ispune na pojasne štapove, ilustrirana je primjena pravila danih u [1].

Ključne riječi: model, proračun priključaka, rešetkasti nosač, šuplji pravokutni profili

\section{DESIGN OF JOINTS IN STEEL TRUSS GIRDERS ACCORDING TO EUROCODES}

\begin{abstract}
This article presents codified design of joints in steel truss girders, according to [1] and [2]. Rules in [1] which refers on welded joints in steel truss girders are specific and valid in very limited conditions. Therefore, it is given a review of those limitations and the procedure of calculation of joint resistance. The application of rules given in [1] is ilustrated on numerical example of steel truss girder, which consists of rectangular hollow sections with direct welding braces members on members of chord.
\end{abstract}

Key words: model, joints design, truss girder, rectangular hollow sections 


\section{Općenito}

Rešetkasti nosači su nastali iz težnje optimalizacije utrošaka materijala uz istovremeno visoko iskorištenje konstrukcije. Rešetkasti nosači sastoje se od pojasnih štapova (gornji i donji pojas) te štapova ispune (dijagonala i/lil vertikala) i predstavljaju konstrukcije koje su racionalne za velike raspone i/li veća opterećenja.

Klasični proračunski model rešetkastih nosača podrazumijeva zglobne veze na mjestima spojeva, tj. pretpostavlja se da su štapovi rešetke izloženi samo djelovanju uzdužnih sila. Takav pristup znatno olakšava provedbu proračuna pa je njegova primjena vrlo raširena u praksi. Međutim, u stvarnosti se veze između štapnih elemenata rešetkastih nosača najčešće izvode kruto (to posebno vrijedi za zavarene spojeve), a ujedno se javljaju i česta odstupanja od centričnog spajanja, što zbog fizičke nemogućnosti ostvarivanja potpuno centričnih veza, što zbog pojednostavljivanja same izvedbe konstrukcije. Zbog nemogućnosti ostvarenja potpuno centričnih veza dolazi do dodatnih naprezanja u štapovima rešetke (tzv. sekundarna naprezanja). Poseban utjecaj na ponašanje rešetke mogu imati priključci između elemenata pa je vrlo bitno procijeniti njihov utjecaj na globalno ponašanje konstrukcije. Pretpostavljanje zglobnih veza na mjestu spojeva štapova rešetkastih nosača vodi do pitanja imaju li kritični dijelovi rešetkastih nosača (elementi ili priključci) dovoljnu duktilnost za ostvarenje te pretpostavke. Potrebni rotacijski kapacitet elemenata može se postići preko ograničavanja vitkosti štapova rešetkastih nosača, gdje posebice treba voditi računa o vitkosti tlačnih štapova. Također je bitan i relativan odnos visina između spojenih elemenata zbog sekundarnih naprezanja. Kada postoji dovoljan rotacijski kapacitet i ako se ekscentricitet nalazi unutar propisanih granica prema [1]:

$$
-0,55 \cdot h_{0} \leq e \leq 0,25 \cdot h_{0}
$$

gdje je $h_{0}$ visina šupljeg kutijastog profila pojasnog štapa u ravnini rešetke, tada se sekundarna naprezanja nastala od momenata savijanja (zbog postojanja krutih, a ne zglobnih veza) mogu zanemariti u proračunima.

Za ilustraciju kodificiranog proračuna priključaka u ovom radu su odabrane zavarene rešetkaste konstrukcije izrađene od šupljih kvadratnih profila, što je često konstrukcijsko rješenje u praksi. Razlikuju se priključci u kojima je ekscentricitet izazvan razmakom između štapova, prikazani na slici 1a, i priključci s ekscentricitetom koji je nastao od preklapanja štapova, prikazani na slici $1 \mathrm{~b}$. Spojevi $\mathrm{s}$ međusobnim preklapanjima imaju veću krutost, ali se, zbog same jednostavnosti izvedbe zavarenih spojeva, češće izvode spojevi s razmacima između štapova.

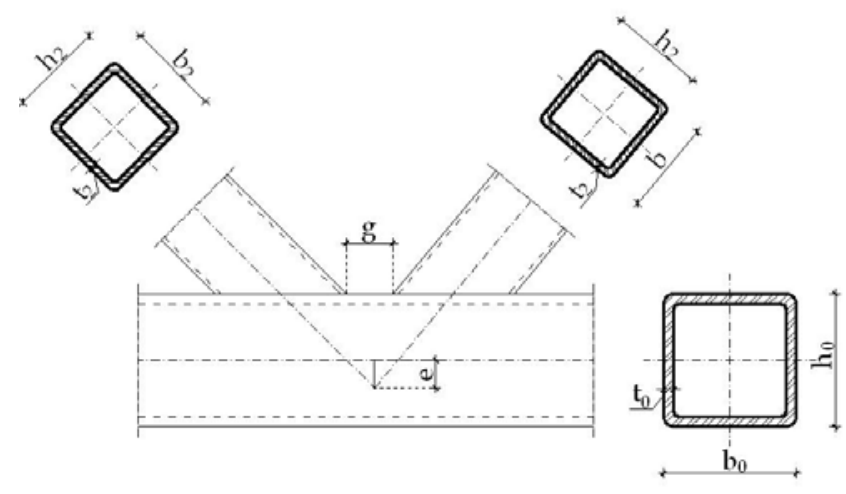

Slika 1a - K priključak s razmakom

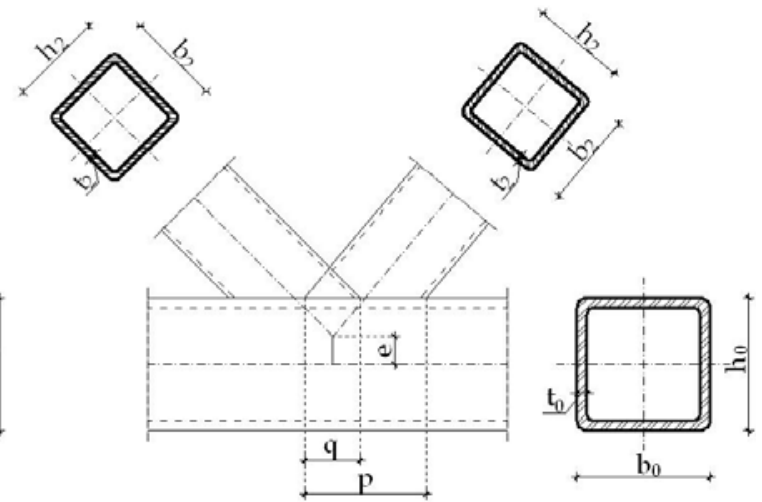

Slika $1 \mathrm{~b}$ - K priključak s preklopom 


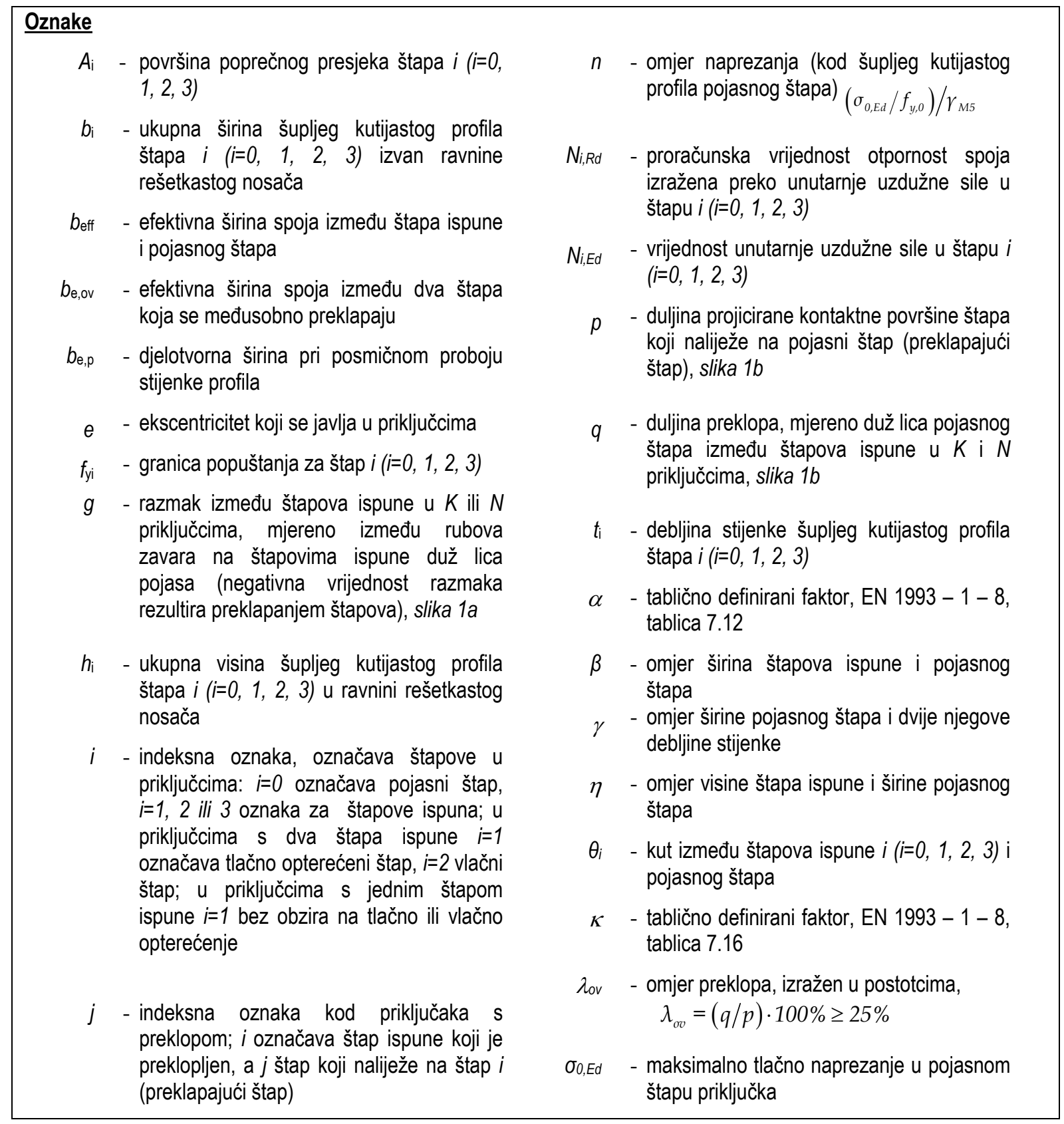

\section{Proračun priključaka u rešetkastim konstrukcijama prema [1]}

Proračun priključaka u čeličnim rešetkastim nosačima, detaljno se opisuje u dijelu [1]. Propisi daju metode proračuna statičke otpornosti priključaka, izražene preko uzdužne sile koju može prenijeti štap ispune i/lii momenta savijanja u štapovima, kod ravninskih i prostornih rešetkastih nosača sastavljenih od okruglih, kvadratnih i pravokutnih šupljih profila, te njihovih međusobnih kombinacija. 
Prema [4] obrađene su karakteristične vrste priključaka u rešetkastim nosačima:

- kod ravninskih rešetki - $K, T, K T, N, X$ i Y priključci

Tablica 1 - Tipovi priključaka u ravninskim rešetkama sa šupljim profilima

\begin{tabular}{|c|c|c|c|}
\hline 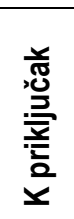 & 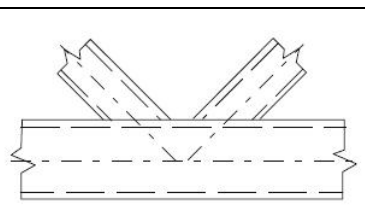 & $\mid \begin{array}{l}h \\
i \\
1 \\
1 \\
1\end{array} \|$ & 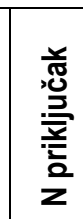 \\
\hline 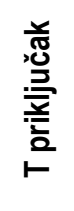 & 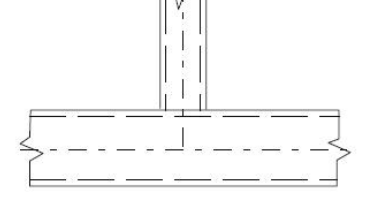 & & 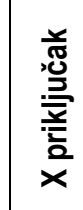 \\
\hline 惫 & $\left\{\begin{array}{l}-\alpha \\
-1\end{array}\right.$ & 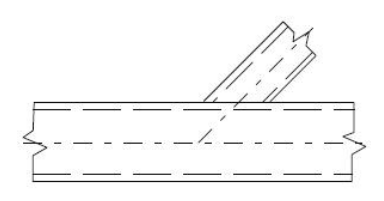 & 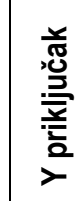 \\
\hline
\end{tabular}

- kod prostornih rešetki - DK, KK, $T T, D Y$ i $X X$ priključci

Tablica 2 - Tipovi priključaka u prostornim rešetkama sa šupljim profilima

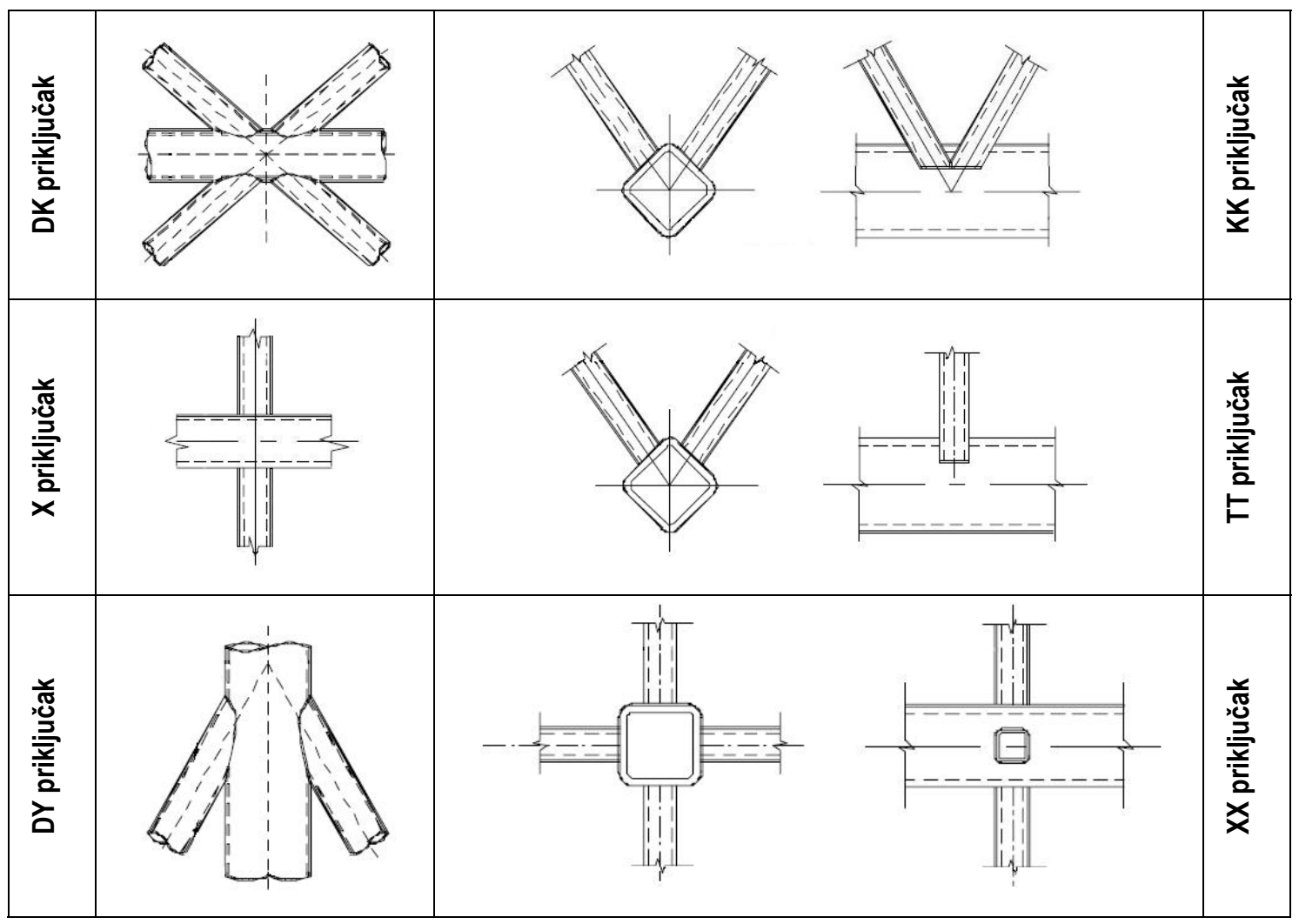


Propisi općenito preporučuju da zavari budu iste ili bolje kvalitete od spojenih elemenata zbog izbjegavanja lomova na samim mjestima zavara. Daju i ograničenja debljina stijenki šupljih poprečnih presjeka: za najmanju debljinu ograničenje je $2,5 \mathrm{~mm}$, a najveća debljina za pojasne štapove se ograničava na $25 \mathrm{~mm}$.

Vrlo su stroga ograničenja u primjeni pravila danih u [1] te se to ovdje posebno izdvaja:

- tlačni štapovi rešetke moraju zadovoljiti uvjete klasifikacije za klasu 1 ili klasu 2 prema pravilima klasifikacije za čisto savijanje, prema [2]

- priključci s preklopom u kojima štapovi imaju različite širine poprečnih presjeka moraju se preklapati tako da je štap s većom širinom preklopljen štapom s manjom širinom

- kutovi između štapova ispune i pojasnih štapova, te između susjednih štapova ispune moraju biti veći od $30^{\circ}$

- priključci s razmakom trebaju imati razmak veći od sume debljina stijenki štapova, mjereno duž lica pojasnog štapa zbog osiguranja izvedbe zavara

- priključci s preklopom trebaju zadovoljiti veličinu preklapanja izraženu u postotcima - ne manja od $25 \%$, preklop treba biti dovoljno velik zbog ostvarenja veze između štapova ispune, tj. radi prijenosa posmične sile iz jenog štapa u drugi

- ako se u priključku s preklopom nalaze štapovi s različitim debljinama stijenki poprečnih presjeka i/ili različitim granicama popuštanja, tada se preklop mora izvesti tako da se štap $s$ manjim vrijednostima $t_{i}$ i $f_{y i}$ nalazi iznad štapa s većim karakteristikama.

Posebno važno pitanje je način utvrđivanja nosivosti/otpornosti priključaka. Nosivost priključaka je izražena preko maksimalne proračunske otpornosti štapova ispune koja ovisi o uzdužnoj sili (u štapu ispune) te ekscentricitetu te sile u odnosu na sjecište osi štapova priključka.

Temeljni modeli za proračun priključaka se uglavnom svode na X i K priključke, a općenito je potrebno razmotriti put sile u štapovima, ponašanje materijala i raspodjelu krutosti.

U [1] se daju sljedeći mogući načini otkazivanja nosivosti priključaka u rešetkastim konstrukcijama:

- otkazivanje nosivosti lica pojasnog štapa (plastifikacijom)

- otkazivanje pojasnog štapa tečenjem, gnječenjem ili nestabilnošću stijenke zbog djelovanja tlačnog štapa ispune

- posmično otkazivanje pojasnog štapa

- posmični proboj stijenke pojasnog štapa (tlačnim štapom), pojava pukotine koja dovodi do odvajanja štapa ispune od pojasa (vlačni štap)

- otkazivanje štapa ispune poradi smanjenja efektivne širine (zbog pukotina u zavarima ili u štapu ispune)

- lokalno izbočivanje štapa ispune ili pojasnog štapa na samom mjestu priključka.

\section{Numerički primjer}

Na primjeru krovne rešetkaste konstrukcije prikazane na slici 3, pokazat će se način proračuna priključaka prema [1] te ukratko opisati i način modeliranja u programskom paketu Autodesk Robot [6].

\subsection{Način modeliranja globalnog ponašanja}

Vanjska djelovanja su koncentrirane sile, a one su stalnog i promjenjivog djelovanja koja su usklađena s [3], detaljnije vidi diplomski rad [7]. Kvaliteta čelika je S355, a u modelima je pretpostavljeno elastično ponašanje čelika. Materijal za zavarivanje je istih svojstava kao i osnovni materijal te je pretpostavljena dovoljno sigurna debljina zavara, tako da nije razmatran način otkazivanja nosivosti preko zavara.

$\mathrm{Na}$ slici 3 vidljiv je pretpostavljeni model rešetkastog nosača. Štapovi rešetkastog nosača dimenzionirani su prema [2], detaljan proračun nosivosti štapova se ovdje posebno ne daje jer to nije tema ovog rada (vidi diplomski $\operatorname{rad}[7])$. 
Tablica 3 - Mogući načini otkazivanja nosivosti priključaka u rešetkastim konstrukcijama prema [1]

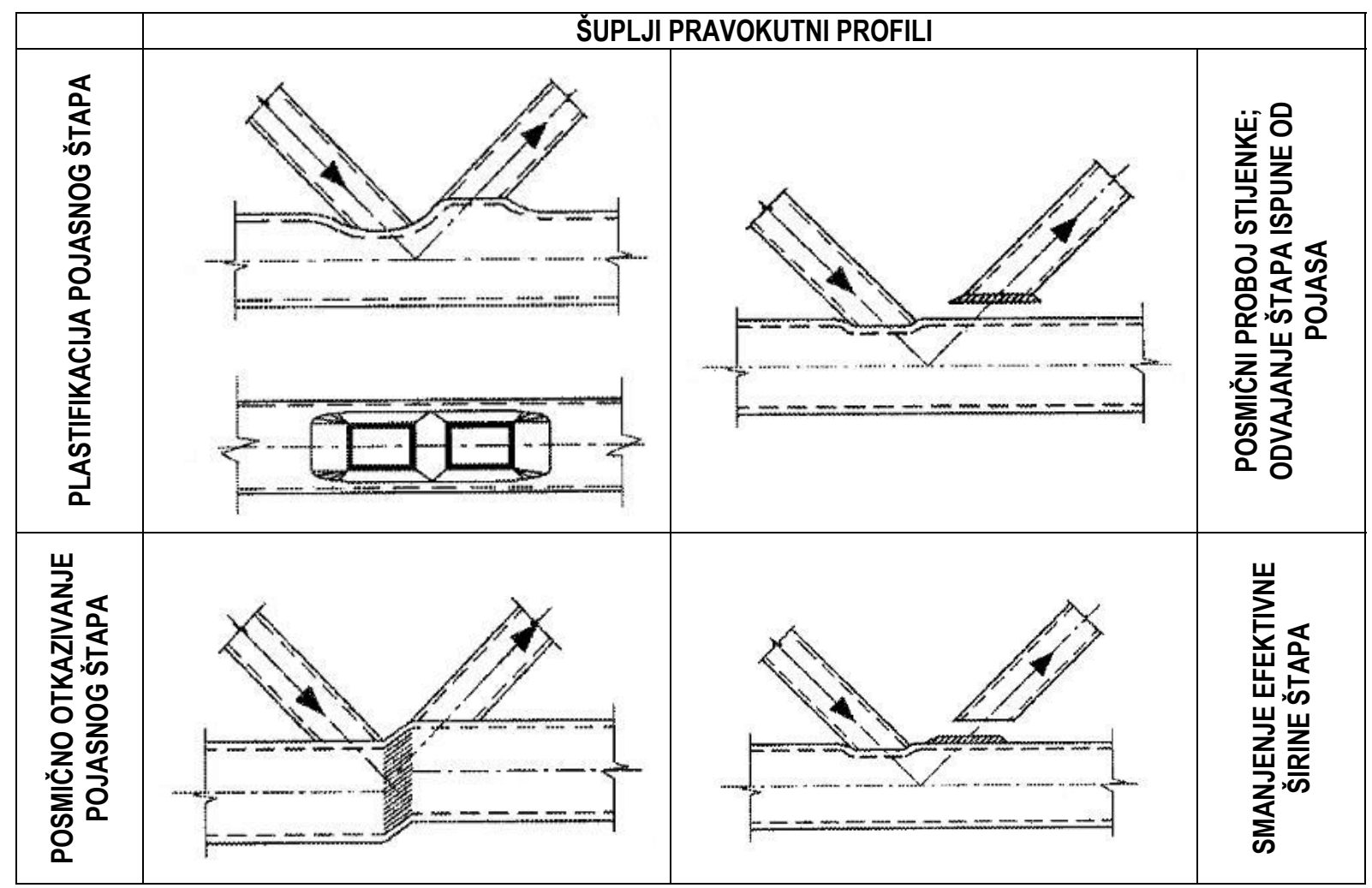

Konstrukcija je modelirana varijantno:

- model priključaka s centrično postavljenim štapovima ispune

- model priključaka s preklopom štapova ispuna i

- model priključaka s razmakom između štapova ispuna, u skladu s [1].

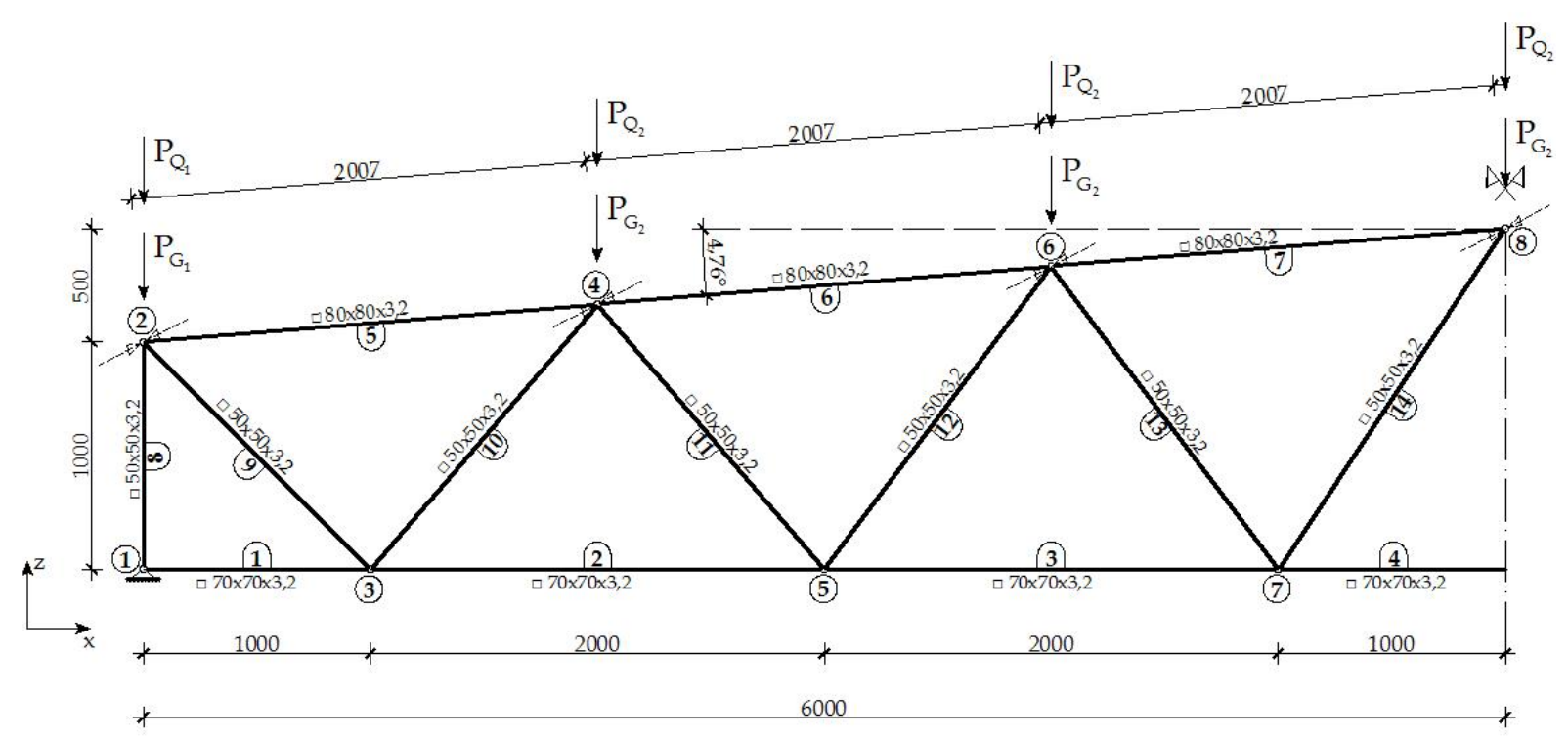

Slika 3 - Shematski prikaz rešetkastog nosača 
Pretpostavljeni model na slici 3 jest model s centričnim sustavom u kojem podrazumjevamo zglobne veze (to je ujedno i osnovni model za globalni proračun), te takvim modelom dobivamo samo uzdužne sile u štapovima. Eventualna naprezanja od savijanja, tzv. sekundarni momenti savijanja se zanemaruju jer ne utječu na ravnotežu.

Modele s preklopima i razmacima smatramo ekscentričnim sustavom te se rešetka tada modelira kao okvirni sustav (veze u čvorovima rešetke više nisu zglobne nego krute). Momenti savijanja koji nastaju zbog ekscentričnog povezivanja štapova rešetke u priključcima se tada ne smatraju sekundarnima, jer mogu utjecati na vrijednosti dobivenih uzdužnih sila u takvom modelu. Međutim, ako se ekscentricitet nalazi unutar ograničenja danih u izrazu 1, ti momenti se mogu zanemariti.

Kada se pri proračunu modelira i postojanje ekscentriciteta u spojevima, koristi se neki od modela prikazanih na slici 4.

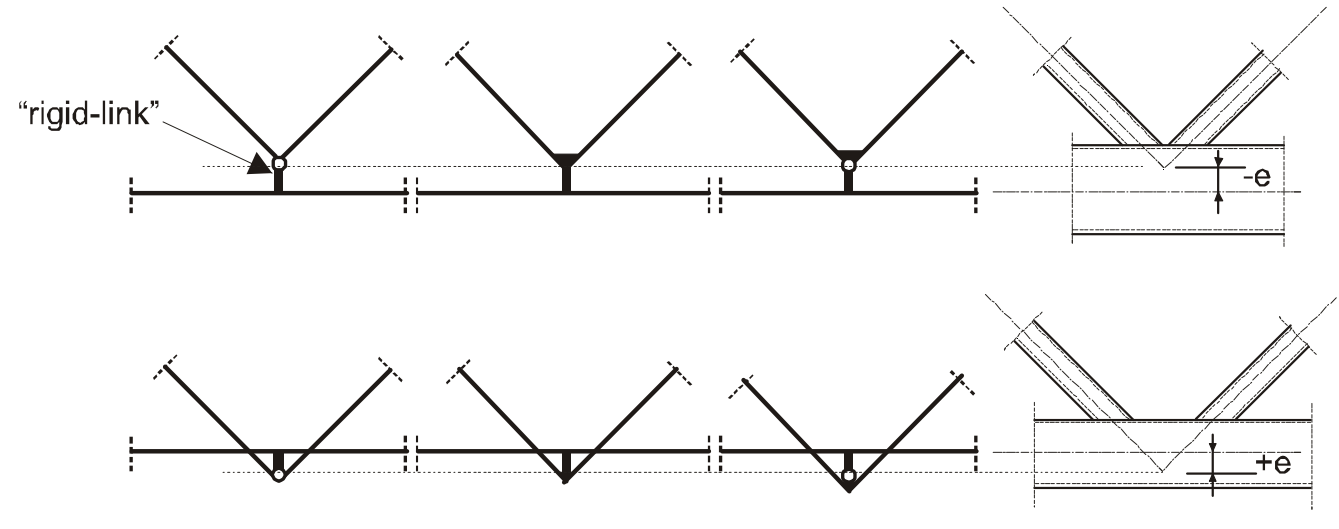

Slika 4 - Prikaz modela s ekscentričnim vezama

\subsection{Proračun karakterističnih priključaka}

U tablici br 4 je dan pregledni tablični prikaz potrebnih izraza za proračun priključaka u odnosu na moguće načine otkazivanja nosivosti priključaka u rešetkama, ([1], poglavlje 7.5.2.1 tablice br 7.10 i 7.12).

Prije provedbe proračuna priključaka potrebno je odrediti neke geometrijske odnose:

$\rightarrow$ omjer širina štapova ispune i pojasnog štapa

$$
\beta=\frac{b_{1}+b_{2}+h_{1}+h_{2}}{4 \cdot b_{0}}
$$

gdje su $b_{i}$ širine šupljih kutijastih profila štapova $i(i=0,1,2,3)$ izvan ravnine rešetke i $h_{i}$ visine šupljih kutijastih profila štapova $i(i=0,1,2,3)$ u ravnini rešetke

$\rightarrow$ omjer širine pojasnog štapa i dvije njegove debljine stijenke

$$
\gamma=\frac{b_{0}}{2 \cdot t_{0}}
$$

gdje su $b_{0}$ širina šupljeg kutijastog pojasnog profila štapa i to debljina stijenke šupljeg kutijastog pojasnog profila štapa. 
Tablica 4 - Proračun otpornosti karakterističnih priključka sa šupljim kvadratnim profilima prema [1]

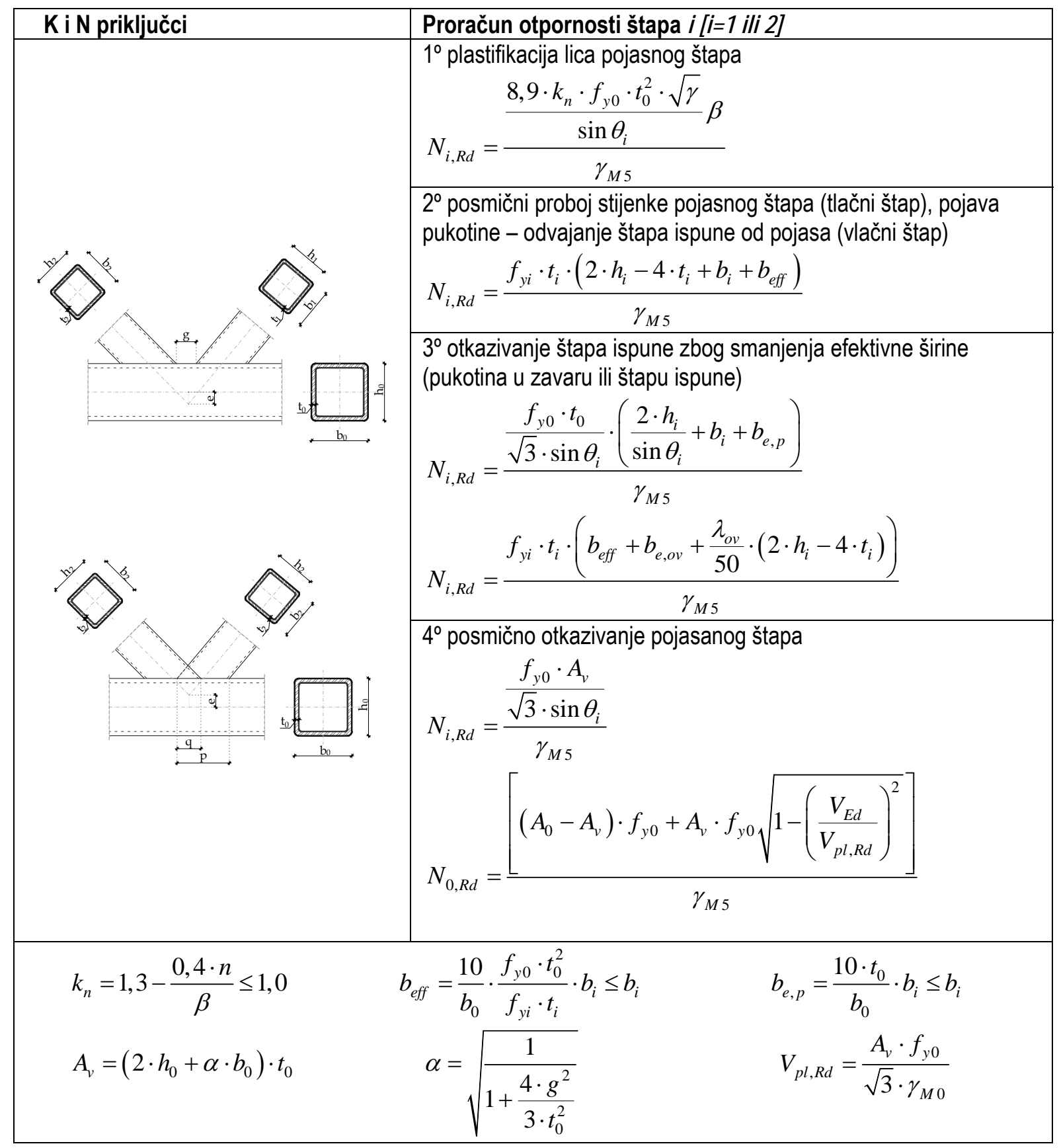

Nadalje se daju pregledni tablični prikazi (tablice 5,6 i 7) potrebnih proračuna priključaka za pretpostavljene modele iz poglavlja 3.1 . 
Tablica 5 - Iskoristivost priključaka rešetkastog nosača - centrično spojeni štapovi

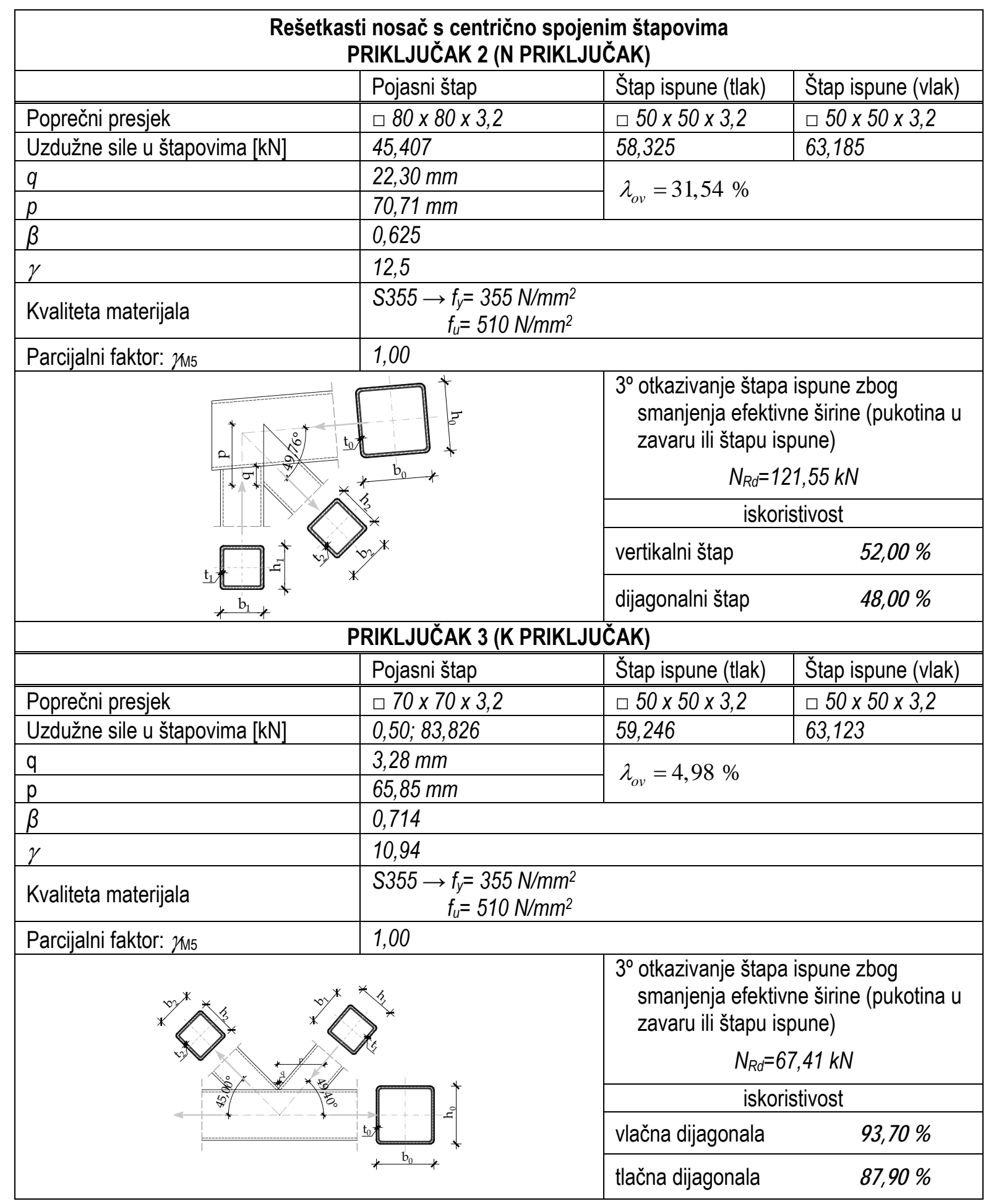

Tablica 5 odnosi se na pretpostavljeni model s centrično spojenim štapovima (pogledati poglavlje 3.1). 
Nastavak tablice 5 - Iskoristivost priključaka rešetkastog nosača - centrično spojeni štapovi

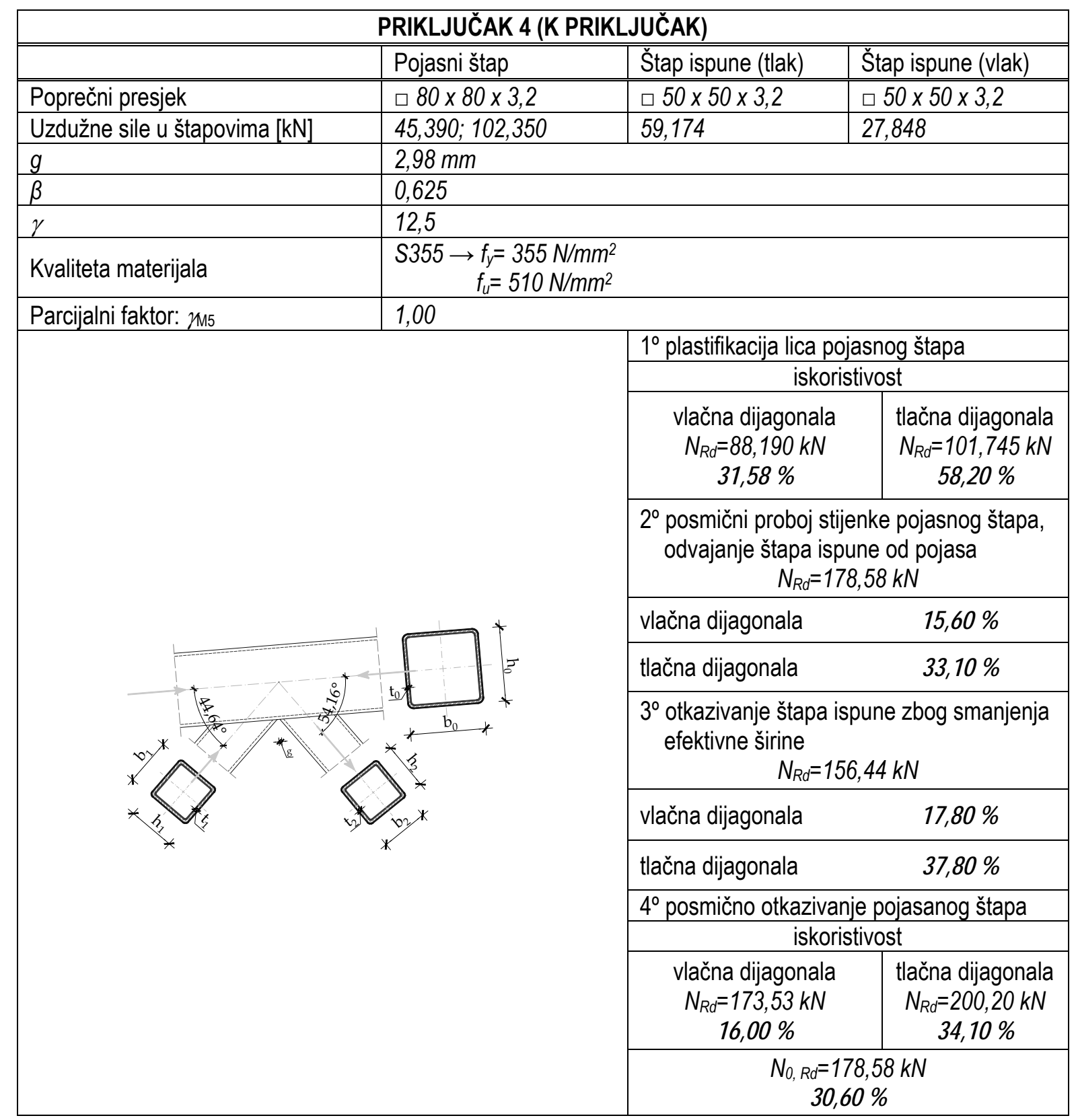

Priključak u rešetkastom nosaču, označen s 2 (pogledati poglavlje 3.1, slika 3), detaljno je prikazan u tablici s proračunom. Proračun tog priključka je isti i u slučaju druga dva pretpostavljena modela, pa nadalje neće biti prikazani. Kod ovakvog pretpostavljenog modela (model s centričnim sustavom u kojem podrazumijevamo zglobne veze) je zaključeno da je priključak 3 (slika 3 ) kritičan priključak u kojem je uočeno otkazivanje preko otkazivanja vlačne ispune zbog smanjenja efektivne širine. 
Tablica 6 - Iskoristivost priključaka rešetkastog nosača - ekscentricitet izazvan razmakom između štapova ispune

\begin{tabular}{|c|c|c|c|}
\hline \multicolumn{4}{|c|}{$\begin{array}{c}\text { Rešetkasti nosač s ekscentrično spojenim štapovima zbog razmaka } \\
\text { PRIKLJUČAK } 3 \text { (K PRIKLJUČAK) }\end{array}$} \\
\hline & Pojasni štap & Štap ispune (tlak) & Štap ispune (vlak) \\
\hline Poprečni presjek & $\square 70 \times 70 \times 3,2$ & $\square 50 \times 50 \times 3,2$ & $\square 50 \times 50 \times 3,2$ \\
\hline Uzdužne sile u štapovima [kN] & 0,$41 ; 88,443$ & 62,754 & 67,116 \\
\hline e & $8 \mathrm{~mm}$ & \multicolumn{2}{|c|}{$(-38,5 \mathrm{~mm}<8 \mathrm{~mm}<17,5 \mathrm{~mm})$} \\
\hline$g$ & \multicolumn{3}{|l|}{$11,025 \mathrm{~mm}$} \\
\hline$\beta$ & \multicolumn{3}{|l|}{0,714} \\
\hline$\gamma$ & \multicolumn{3}{|l|}{10,94} \\
\hline Kvaliteta materijala & \multicolumn{3}{|l|}{$\begin{array}{r}S 355 \rightarrow f_{y}=355 \mathrm{~N} / \mathrm{mm}^{2} \\
f_{u}=510 \mathrm{~N} / \mathrm{mm}^{2}\end{array}$} \\
\hline Parcijalni faktor: $\gamma_{M 5}$ & \multicolumn{3}{|l|}{1,00} \\
\hline \multirow{13}{*}{$\sum_{\substack{2 \\
2}}^{2}$} & & \multirow{2}{*}{\multicolumn{2}{|c|}{$\begin{array}{c}1^{0} \text { plastifikacija lica pojasnog štapa } \\
\text { iskoristivost }\end{array}$}} \\
\hline & & & \\
\hline & & $\begin{array}{c}\text { vlačna dijagonala } \\
N_{R d}=107,653 \mathrm{kN} \\
\mathbf{6 2 , 3 4 \%}\end{array}$ & $\begin{array}{c}\text { tlačna dijagonala } \\
N_{R d}=100,255 \mathrm{kN} \\
\mathbf{6 2 , 6 0 \%}\end{array}$ \\
\hline & & \multicolumn{2}{|c|}{$\begin{array}{c}2^{0} \text { posmični proboj stijenke pojasnog } \\
\text { štapa, odvajanje štapa ispune od pojasa } \\
N_{R d}=197,44 \mathrm{kN}\end{array}$} \\
\hline & & \multicolumn{2}{|l|}{ vlačna dijagonala } \\
\hline & & \multicolumn{2}{|l|}{ tlačna dijagonala } \\
\hline & & \multicolumn{2}{|c|}{$\begin{array}{c}3^{0} \text { otkazivanje štapa ispune zbog } \\
\text { smanjenja efektivne širine } \\
N_{R d}=181,82 \mathrm{kN} \\
\end{array}$} \\
\hline & & \multicolumn{2}{|l|}{ vlačna dijagonala } \\
\hline & & \multicolumn{2}{|l|}{ tlačna dijagonala } \\
\hline & & \multicolumn{2}{|c|}{$4^{0}$ posmično otkazivanje pojasanog štapa } \\
\hline & & \multicolumn{2}{|c|}{ iskoristivost } \\
\hline & & $\begin{array}{c}\text { vlačna dijagonala } \\
N_{R d}=145,10 \mathrm{kN} \\
\mathbf{4 6 , 3 0 \%}\end{array}$ & $\begin{array}{c}\text { tlačna dijagonala } \\
N_{R d}=135,13 \mathrm{kN} \\
\mathbf{4 3 , 2 0} \%\end{array}$ \\
\hline & & \multicolumn{2}{|c|}{$\begin{array}{l}N_{0, R d}=276,06 \mathrm{kN} \\
32,00 \%\end{array}$} \\
\hline
\end{tabular}

Tablica 6 odnosi se na pretpostavljeni model s ekscentrično spojenim štapovima zbog zadovoljenja propisom određenog razmaka (pogledati poglavlje 3.1). 
Nastavak tablice 6 - Iskoristivost priključaka rešetkastog nosača - ekscentricitet izazvan razmakom između štapova ispune

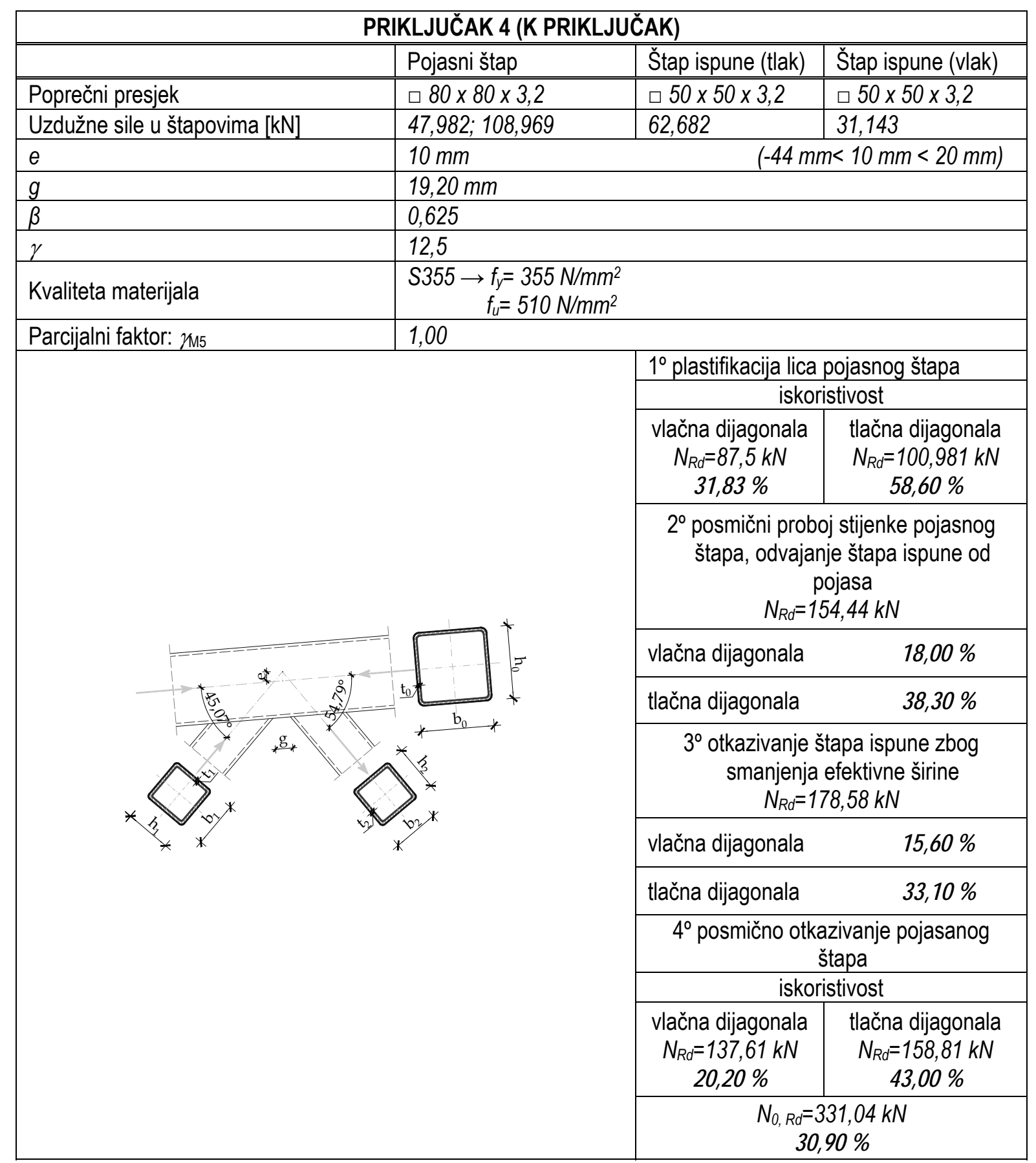


Tablica 7 - Iskoristivost priključaka rešetkastog nosača - ekscentricitet izazvan međusobnim preklopom štapova ispune

\begin{tabular}{|c|c|c|c|}
\hline \multicolumn{4}{|c|}{$\begin{array}{c}\text { Rešetkasti nosač s ekscentrično spojenim štapovima zbog preklopa štapova } \\
\text { PRIKLJUČAK } 3 \text { (K PRIKLJUČAK) }\end{array}$} \\
\hline & Pojasni štap & Štap ispune (tlak) & Štap ispune (vlak) \\
\hline Poprečni presjek & $\square 70 \times 70 \times 3,2$ & $\square 50 \times 50 \times 3,2$ & $\square 50 \times 50 \times 3,2$ \\
\hline Uzdužne sile u štapovima [kN] & 0,$613 ; 83,961$ & 59,161 & 62,609 \\
\hline e & \multicolumn{3}{|c|}{$(-38,5 \mathrm{~mm}<-8 \mathrm{~mm}<17,5 \mathrm{~mm})$} \\
\hline$q$ & $17,89 \mathrm{~mm}$ & \multirow{2}{*}{\multicolumn{2}{|c|}{$\lambda_{o v}=26,94 \%$}} \\
\hline$p$ & $66,40 \mathrm{~mm}$ & & \\
\hline$\beta$ & \multicolumn{3}{|l|}{0,714} \\
\hline Kvaliteta materijala & \multicolumn{3}{|l|}{$\begin{aligned} S 355 \rightarrow f_{y} & =355 \mathrm{~N} / \mathrm{mm}^{2} \\
f_{u} & =510 \mathrm{~N} / \mathrm{mm}^{2}\end{aligned}$} \\
\hline Parcijalni faktor: $2 M 5$ & \multicolumn{3}{|l|}{1,00} \\
\hline \multirow{4}{*}{ 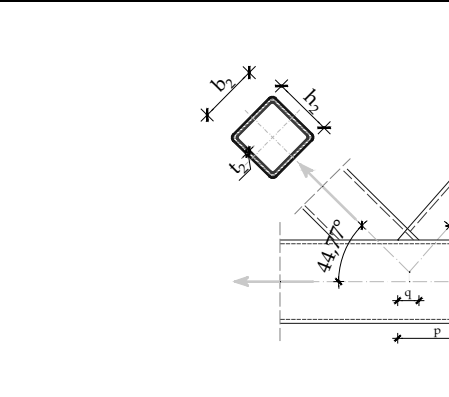 } & \multirow{4}{*}{$\underbrace{t}_{*}+$} & \\
\hline & & \\
\hline & & \multicolumn{2}{|c|}{$\begin{array}{c}3^{\circ} \text { otkazivanje štapa ispune zbog } \\
\text { smanjenja efektivne širine (pukotina u } \\
\text { zavaru ili štapu ispune) } \\
N_{R d}=216,97 \mathrm{kN} \\
\text { iskoristivost }\end{array}$} \\
\hline & & \multicolumn{2}{|l|}{ tlačna dijagonala } \\
\hline \multicolumn{4}{|c|}{ PRIKLJUČAK 4 (K PRIKLJUČAK) } \\
\hline & Pojasni štap & Štap ispune (tlak) & Štap ispune (vlak) \\
\hline Poprečni presjek & $\square 80 \times 80 \times 3,2$ & $\square 50 \times 50 \times 3,2$ & $\square 50 \times 50 \times 3,2$ \\
\hline Uzdužne sile u štapovima [kN] & 45,407 & 58,325 & 63,185 \\
\hline e & \multicolumn{2}{|l|}{$-14 \mathrm{~mm}$} & $44 \mathrm{~mm}<-14 \mathrm{~mm}<20 \mathrm{~mm})$ \\
\hline$q$ & $20,91 \mathrm{~mm}$ & \multirow{2}{*}{\multicolumn{2}{|c|}{$\lambda_{o v}=33,69 \%$}} \\
\hline$p$ & $62,08 \mathrm{~mm}$ & & \\
\hline$\beta$ & \multicolumn{3}{|l|}{0,625} \\
\hline Kvaliteta materijala & \multicolumn{3}{|l|}{$\begin{aligned} S 355 \rightarrow f_{y} & =355 \mathrm{~N} / \mathrm{mm}^{2} \\
f_{u} & =510 \mathrm{~N} / \mathrm{mm}^{2}\end{aligned}$} \\
\hline Parcijalni faktor: zMS & \multicolumn{3}{|l|}{1,00} \\
\hline & $\sum_{b_{0}}{ }^{5}$ & \multicolumn{2}{|c|}{$\begin{array}{l}3^{0} \text { otkazivanje štapa ispune zbog } \\
\text { smanjenja efektivne širine (pukotina u } \\
\text { zavaru ili štapu ispune) } \\
N_{R d}=272,0 \mathrm{kN}\end{array}$} \\
\hline & & \multicolumn{2}{|c|}{ iskoristivost } \\
\hline & & vlačna dijagonala & $10,20 \%$ \\
\hline z & & tlačna dijagonala & $21,80 \%$ \\
\hline
\end{tabular}

Urađen je i proračun priključaka u posebnom modulu programskog paketa Autodesk Robot [6], te je za usporedbu prikazan priključak br 3 (pogledati poglavlje 3.1, slika 3). 

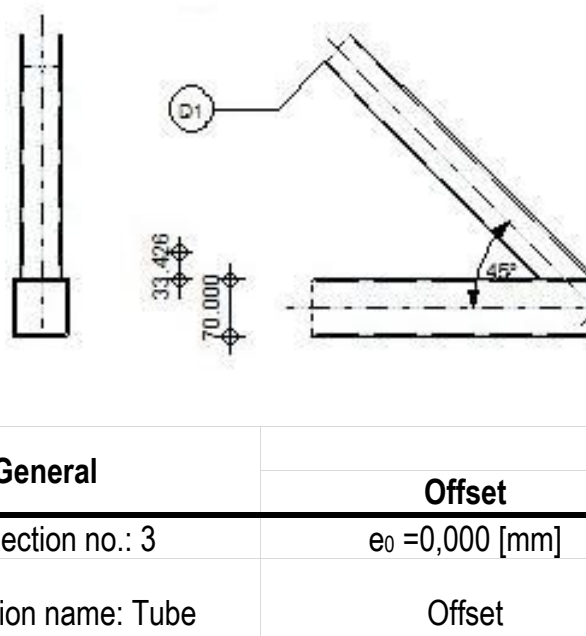

General

Connection no.: 3

$e_{0}=0,000[\mathrm{~mm}]$

Spacings

Welds

Connection name: Tube

Offset

Spacing of 2 nd diagonal

$a_{d}=5,000[\mathrm{~mm}]$

Thickness of welds of diagonals and posts

Bars

\begin{tabular}{|c|c|c|c|c|c|c|}
\hline & Ch & & \multirow{2}{*}{\multicolumn{2}{|c|}{$\begin{array}{c}\text { Diagonal } 1 \\
\text { TCAR } 50 \times 3.2\end{array}$}} & \multirow{2}{*}{\multicolumn{2}{|c|}{$\begin{array}{c}\text { Diagonal } 2 \\
\text { TCAR 50×3.2 }\end{array}$}} \\
\hline Section & \multicolumn{2}{|c|}{ TCAR 70x3.2 } & & & & \\
\hline \multirow{6}{*}{ Loads } & $\mathrm{N}_{01, \mathrm{Ed}}=-0,5[\mathrm{kN}]$ & Axial force & \multirow{3}{*}{$\mathrm{N}_{1}=-63,1[\mathrm{kN}]$} & \multirow{3}{*}{$\begin{array}{l}\text { Axial } \\
\text { force }\end{array}$} & \multirow{3}{*}{$\mathrm{N}_{2}=59,2[\mathrm{kN}]$} & \multirow{3}{*}{ Axial force } \\
\hline & $\mathrm{M}_{01, \mathrm{Ed}}=0[\mathrm{kNm}]$ & $\begin{array}{l}\text { Bending } \\
\text { moment }\end{array}$ & & & & \\
\hline & $Q_{01, E d}=0[k N]$ & Shear force & & & & \\
\hline & $\mathrm{N}_{02, \mathrm{Ed}}=-83,8[\mathrm{kN}]$ & Axial force & & & & \\
\hline & $\mathrm{M}_{02, \mathrm{Ed}}=0[\mathrm{kNm}]$ & $\begin{array}{l}\text { Bending } \\
\text { moment }\end{array}$ & $\mathrm{M}_{1}=0[\mathrm{kNm}]$ & $\begin{array}{l}\text { Bending } \\
\text { moment }\end{array}$ & $\mathrm{M}_{2}=0[\mathrm{kNm}]$ & $\begin{array}{l}\text { Bending } \\
\text { moment }\end{array}$ \\
\hline & $Q_{02, E d}=0[k N]$ & Shear force & & & & \\
\hline
\end{tabular}

\section{Results}

Capacity verification Eurocode 3: EN 1993-1-8:2005

\section{Diagonal 2}

\begin{tabular}{|c|c|c|c|}
\hline$\lambda_{\mathrm{ov}}=$ & 4,45 & {$[\%]$} & Value of the overlap of bars \\
\hline$b_{\text {eff }}$ & 22,85 & [mm] & $\begin{array}{l}\text { Effective width in the connection of } \\
\text { the diagonal to the chord }\end{array}$ \\
\hline$b_{e, 0}$ & 32,00 & [mm] & $\begin{array}{l}\text { Effective width for the overlapping } \\
\text { diagonal }\end{array}$ \\
\hline $\mathrm{IN} 2, \mathrm{Rd}-$ & 70,52 & {$[\mathrm{kN}]$} & Compression capacity \\
\hline
\end{tabular}

[Table7.10] $\left|N_{2}\right| \leq N_{2, R d}$

$$
\begin{aligned}
& b_{\text {eff }}=\left[10 /\left(b_{0} / t_{0}\right)\right]^{*}\left[f_{0}^{*} t_{0} /\left(f_{2}{ }^{*} t_{2}\right)\right]^{*} b_{2} \\
& b_{e, o v}=\left[10 /\left(b_{1} / t_{1}\right)\right]^{*}\left[f_{1}^{*}{ }^{*} t_{1} /\left(f_{2}{ }^{*} t_{2}\right)\right]^{*} b_{2}
\end{aligned}
$$

$\mathrm{N}_{2, \mathrm{Rd}}=\mathrm{f}_{2}{ }^{*} \mathrm{t}_{2}{ }^{*}\left[\mathrm{~b}_{\mathrm{eff}}+\mathrm{b}_{\mathrm{e}, \mathrm{ov}}+\lambda_{\mathrm{ov}} / 50 *\left(2{ }^{*} \mathrm{~h}_{2}-4^{*} \mathrm{t}_{2}\right)\right] / \mathrm{\gamma}_{\mathrm{M} 5}$ verified $(0,84)$

\section{Diagonal 1}

\begin{tabular}{ll|l|l}
$\lambda_{\text {ov }}=$ & 4,45 & {$[\%]$} & Value of the overlap of bars
\end{tabular}

$b_{\text {eff }}=22,85 \quad[\mathrm{~mm}]$ Effective width in the connection of

the diagonal to the chord

Effective width for the overlapping

$\mathrm{b}_{\mathrm{e}, \mathrm{ov}}=32,00 \quad[\mathrm{~mm}]$ diagonal

\begin{tabular}{ll|l}
$\mathrm{N}_{1, R d}=\quad 70,52$ & {$[\mathrm{kN}]$} & Compression capacity
\end{tabular}

[Table7.10]

$\left|N_{1}\right| \leq N_{1, R d}$

$|-63,116|<70,521$

$$
\begin{aligned}
& b_{\text {eff }}=\left[10 /\left(b_{0} / t_{0}\right)\right]^{*}\left[f_{0}^{*} t_{0} /\left(f_{1}{ }^{*} t_{1}\right)\right]^{*} b_{1} \\
& b_{e, o v}=\left[10 /\left(b_{1} / t_{1}\right)\right]^{*}\left[f_{1}^{*} t_{1} /\left(f_{1}{ }^{*} t_{1}\right)\right]{ }^{*} b_{1}
\end{aligned}
$$

$\mathrm{N}_{1, \mathrm{Rd}}=\mathrm{f}_{1}{ }^{*} \mathrm{t}_{1}{ }^{*}\left[\mathrm{~b}_{\text {eff }}+\mathrm{b}_{\mathrm{e}, \mathrm{ov}}+\lambda_{\text {ov }} / 50 *\left(2^{*} \mathrm{~h}_{1}-4^{*} \mathrm{t}_{1}\right)\right] / \mathrm{Y}_{\mathrm{M} 5}$ verified

$(0,90)$ 


\section{Zaključak}

U radu je detaljnije prikazan način proračuna priključaka rešetkastih nosača prema [1]. Proračun priključaka u skladu s Eurokod normom je vrlo specifičan te sadrži brojna ograničenja u primjeni s obzirom na dimenzije i geometriju nosača.

Za modeliranje rešetke su u radu korišteni štapni modeli, a osnovni štapni model na kojem je proveden globalni proračun od kojega se polazi, jest model s centrično spojenim štapovima. Potom su izrađena još dva modela koji se baziraju na ekscentrično spojenim štapovima u području priključaka. U prvom modelu izvedbom razmaka između štapova ispuna, a u drugom preklapanjem štapova ispuna. Stoga su za ovako pretpostavljene modele varirane proračunske pretpostavke - u slučaju modela s centričnim sustavom pretpostavljene su zglobne veze, dok su u modelima s ekscentričnim sustavom veze kruto ostvarene. Treba još naglasiti da u štapnom modeliranju kakvo je ovdje primjenjeno, nije moguće u obzir uzeti lokalno ponašanje priključaka, za što bi trebalo načiniti 3D shell model priključaka ili 3D shell model cijelog rešetkastog nosača, međutim to je zahtjevniji posao (vidi rad [5]).

Zaključno se može reći da se na ovom području može i dalje provoditi eksperimentalna i numerička istraživanja za uvjete spojeva i geometrije koji još nisu kodificirani.

\section{$5 \quad$ Literatura}

[1] European Committee for Standardization (CEN) 2005: EN 1993 - 1 - 8, Eurocode 3: Design of steel structures - Part 1 - 8: Design of joints

[2] European Committee for Standardization (CEN) 2005: EN 1993 - 1 - 1, Eurocode 3: Design of steel structures - Part 1-1: General rules and rules for buildings

[3] European Committee for Standardization (CEN) 2001: EN 1991 - 1 - 1, Eurocode 1: Actions on structures Part 1-1: General actions - Densities, self - weight, imposed loads for bildings

[4] WARDENIER, J. 2001: Hollow sections in structural applications, Comitè International pour le Dèveloppement et l'Etude de la Construction Tubulaire, CIDECT.

[5] Radić, I.; Markulak, D.; Mikolin, M. 2010: Design and FEM Modelling of Steel Truss Girder Joints; Strojarstvo, $52(2), 125-135$

[6] AUTODESK ROBOT STRUCTURAL ANALYSIS: Getting started guide,2009., Autodesk, Inc.

[7] Knežević, I. 2010: Diplomski rad, Sveučilište J. J. Strossmayera u Osijeku, Građevinski fakultet, Osijek 